\title{
Production and Characteristics of Composite Edible Films Based on Polysaccharides and Proteins
}

\author{
Edy Subroto $^{1}$, Rossi Indiarto ${ }^{2}$, Aldila Din Pangawikan ${ }^{3}$, FauziAtsaniHarits Prakoso ${ }^{4}$ \\ Department of Food Industrial Technology, Faculty of Agro-Industrial Technology, UniversitasPadjadjaran,

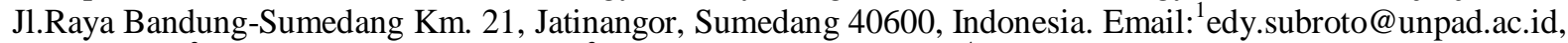 \\ ${ }^{2}$ rossi.indiarto@unpad.ac.id, ${ }^{3}$ pangawikan@unpad.ac.id, ${ }^{4}$ fauzi15001@mail.unpad.ac.id
}

\begin{abstract}
The use of plastic materials as food packaging materials has caused environmental problems, namely the accumulation of plastic waste. The presence of innovation in making food packaging with organic materials in the form of edible films can minimize plastic waste because organic materials can be degraded by decomposing microbes in a relatively short time. This review examines the production and characteristics of composite edible films based on polysaccharides and proteins. Several characteristics of the material that this film must meet, such as resistance to water and evaporation, are the standards that must be met for edible films. Starch-based materials are still too brittle to be the base material for making films because the hydrophilic nature of starch makes it easy to dissolve in water. The functional properties of starch need to be improved, including mixing it with other ingredients such as proteins, plasticizers, and essential oils in formulations. The mixing of these ingredients can form a formulation that forms an edible film with characteristics suitable for various food products.
\end{abstract}

Key words: Edible film, polysaccharide, starch, whey protein packaging material.

\section{INTRODUCTION}

The overflow of food packaging, especially from plastic, has become an environmental issue that can cause various problems in the future. Therefore, it is necessary to have innovation in the selection of organic food packaging materials so that they will be more biodegradable and environmentally friendly. Organic food packaging is a package made of organic materials such as lipids, proteins, and polysaccharides, which are easier to decompose and are edible or safe for consumption [1]. This packaging is generally in the form of a film or a transparent plastic layer [2].

Edible film packaging made from organic materials must be able to protect food from environmental contamination physically, chemically, and biologically. Generally, the functions of food packaging are to prolong the shelf life of food[3]. The edible film has several criteria that must be met, including the strength of the film to withstand tension (tensile strength), film elasticity (elongation), thickness, and the ability to withstand water vapor [4]. In principle, film and coating are two different things but are often considered the same. The edible film is a layer formed from organic materials such as polysaccharides, fat, and protein, which functions to cover or wrap a food product to protect it from various contaminants. Meanwhile, the edible coating is a layer that is directly attached to the entire surface of food products, which has the same function as edible film, which protects products from contaminants [5].

Edible films are generally synthesized from polysaccharides, especially starch-based materials. However, starch-based films are known to have characteristics that are less resistant to maintaining food moisture. The lack of elasticity of the starch-based film also makes the structure easy to detach so that it is prone to tearing [6]. However, the use of polysaccharide-based films is known to have good permeability so that it can reduce gas molecules that enter or leave [7]. This has led to many studies that formulate starch with other organic materials to modify the structure of the film into a composite. One of the ingredients commonly used is protein. The starch formulation with this protein is synergistic because protein has characteristics that can form a flexible film and do not tear easily [8].

The use of protein can rectify the physical characteristics of the film. The use of proteins such as whey protein can also enhance the antimicrobial properties of the film. Whey made from milk products or their derivatives contains the enzyme lysozyme, which is often found in various animal secretion products. This lysozyme has an antimicrobial effect given to the film [9]. Fermentation treatment of whey by proteolytic microorganisms can also produce bioactive compounds in the form of lactoferricin, which increases the antimicrobial properties of the film. These bioactive compounds are the result of the breakdown of lactoferrin peptides by Candida tropicalis[10].

Starch and protein-based edible films can continue to be developed due to the abundance of starch and protein sources in nature. The use of various types of starch for the synthesis of edible films has great potential. This is because these materials available in abundance and environmentally 
Edy Subroto et al., International Journal of Emerging Trends in Engineering Research, 9(2), February 2021, 42 - 48

friendly [11]. On the other hand, some protein sources, such as whey protein, are also an abundant source of protein because it is a waste of the cheese processing industry resulting from the separation of fat and casein, which also has good potential. Whey protein, which is considered waste, still contains at least $55 \%$ of nutrients that can still be utilized [12].

The formulation of starch and protein-based edible films is expected to produce good quality films as biodegradable, edible films and can be used in the pharmaceutical and food industries. This review describes the production and characteristics of composite edible films based on polysaccharides(especiallystarch) and protein. The good quality of the edible film will extend the shelf life of food by inhibiting or preventing the spoilage caused by many factors.

\section{POLYSACCHARIDES BASED EDIBLE FILM}

Polysaccharide-based films are very good at protecting foods from $\mathrm{O}_{2}$ and $\mathrm{CO}_{2}$ as well as from various fats. Some materials that can be used as polysaccharide-based films include chitosan, pectin, cellulose, starch, algin extract, and gum. Starch is one of the ingredients that is often chosen because of its availability from a variety of materials, economical, and non-toxic [13]. Polysaccharide-based film coating is colorless, oil-free, and contains low calories. This film can also be applied to extend the shelf life of vegetables, fruits, and meat products or shellfish by reducing the browning reactions, dehydration, and oxidative rancidity [14]. The characteristics of films on different types of polysaccharides can be seen in Table 1 .

Table 1.Characteristics of films on different types of polysaccharides.

\begin{tabular}{|c|c|c|c|}
\hline $\begin{array}{c}\text { Types of } \\
\text { Polysaccharid } \\
\text { es }\end{array}$ & $\begin{array}{c}\text { plasticizer } \\
\text { / Essential } \\
\text { Oil }\end{array}$ & Film characteristics & $\begin{array}{c}\text { Refere } \\
\text { nces }\end{array}$ \\
\hline Chitosan & Glycerol & $\begin{array}{l}\text { Thickness } 93-130 \\
\mu \mathrm{m} \text { (thin), moist, } \\
\text { water-soluble, } \\
\text { bright yellow color, } \\
\text { low density, high } \\
\text { WVTR. }\end{array}$ & [18] \\
\hline Pectin methyl & Glycerol & $\begin{array}{l}40 \mu \mathrm{m} \text { thickness } \\
\text { (thin), good tensile } \\
\text { strength, poor } \\
\text { elastic modulus, } \\
\text { high WVTR, many } \\
\text { fraction } \\
\text { texture. }\end{array}$ & [19] \\
\hline $\mathrm{CMC}$ & Glycerol & $\begin{array}{l}\text { The thickness is } 87 \\
\mu \mathrm{m} \text { (thin), TS is } \\
\text { good, elongation is } \\
\text { not good, } \\
\text { transparent, smooth } \\
\text { texture. }\end{array}$ & [20] \\
\hline $\begin{array}{l}\text { Sodium } \\
\text { alginate }\end{array}$ & $\begin{array}{l}\text { Essential } \\
\text { Oil }\end{array}$ & $\begin{array}{l}\text { Thickness } \\
0.101-0.106 \quad \mathrm{~mm}\end{array}$ & [21] \\
\hline
\end{tabular}

\begin{tabular}{|c|c|c|}
\hline & & $\begin{array}{l}\text { (thick), slightly } \\
\text { yellow, less humid, } \\
\text { low WVP, good } \\
\text { elongation, less } \\
\text { good TS. }\end{array}$ \\
\hline $\begin{array}{c}\text { Cassava } \\
\text { starch }\end{array}$ & Glycerol & $\begin{array}{l}\text { Tensile strength is } \\
\text { not good, } \\
\text { transparent, and the } \\
\text { color is bright, low } \\
\text { density, low WVP, } \\
\text { and less moisture. }\end{array}$ \\
\hline Ghatti gum & Glycerol & $\begin{array}{l}\text { The thickness of } \\
0.033 \mathrm{~mm} \text { (thin), } \\
\text { less moisture, } \\
\text { bright transparent, } \\
\text { TS is not good, low } \\
\text { WVP. }\end{array}$ \\
\hline
\end{tabular}

Some polysaccharides such as chitosan and cellulose are difficult to dissolve in water, making application difficult. In order to increase its solubility, it is necessary to modify it chemically so that the material dissolves in water. Meanwhile, dissolving alginate and pectin extracts requires the adjunct of calcium ions to form a gel[15]. Polysaccharides are good barriers to carbon dioxide and oxygen due to the dense network construction of polysaccharides, but they are not a good vapor barrier. In addition, polysaccharide-based films will lose their ability as a gas barrier when a plasticizer is added to the formulation. This is another limitation of polysaccharides. Various ways, such as the addition of water-resistant inorganic particles, the combination with polymer cross-linking,lipids, and the fabrication of multilayered or composite films, can be used to improve water resistance and barrier characteristics[16], [17].

The most commonly used polysaccharides in making edible films are starch. Various sources of starch have been utilized for the production of edible films. Starch is one of the most promising polysaccharides that form edible films because it is a renewable, versatile, cheap, and very abundant material [24]. The use of starch as a material for making films is because starch has characteristics that are more economical, odorless, and colorless. However, the characteristics given by starch to the film due to the hydrophilic properties of starch make it unable to maintain the moisture of the packaged food [25]. Therefore it is necessary to make modifications to improve the function of starch as an ingredient for the production of edible films. Starch modification can improve water vapor permeability and physicochemical properties [26].

\section{PROTEIN-BASED FILMS}

The use of edible films as food packaging is very effective in preventing the loss of moisture and taste, reducing the activity of gas in and out (carbon dioxide, oxygen, and 
Edy Subroto et al., International Journal of Emerging Trends in Engineering Research, 9(2), February 2021, 42 - 48

ethylene), and packaging can be designed to have bioactive compounds (for example, antimicrobials, antioxidants, or nutraceuticals) [27]. In addition, protein-based edible films are rich in nitrogen, which functions as organic fertilizer for the soil, so that concerns about environmental damage due to disposal of edible films to the soil can be avoided [28].

This protein-based film is ideal for use in a product with a hydrophilic surface that is coated or wrapped with a film and as a good barrier to $\mathrm{O}_{2}$ and $\mathrm{CO}_{2}$. However, this protein-based film does not withstand water diffusion. With the addition of plasticizers such as glycerol and hydrophobic materials such as beeswax, it can modify the properties of proteins to water resistance [29], [30]. Some protein sources that can be used as material for making films of animal origin include whey protein, casein, gelatin, and egg albumin. Meanwhile, available protein comes from plants, including protein from peanuts, soybeans, corn, rice, and wheat [30], [31]. The characteristics of films on different types of proteins can be seen in Table 2.

Table 2.Characteristics of films on different types of proteins.

\begin{tabular}{|c|c|c|c|}
\hline $\begin{array}{l}\text { Source of } \\
\text { Proteins }\end{array}$ & $\begin{array}{c}\text { Plastisizer/ } \\
\text { Essential } \\
\text { Oil }\end{array}$ & $\begin{array}{c}\text { Characteristics of } \\
\text { film }\end{array}$ & References \\
\hline $\begin{array}{l}\text { Whey } \\
\text { protein }\end{array}$ & $\begin{array}{l}\text { Glycerol } \\
\text { and } \\
\text { Essential } \\
\text { Oil }\end{array}$ & $\begin{array}{l}\text { Film thickness } 9 \mathrm{~mm} \\
\text { (thickness), } \\
\text { yellowish color, } \\
\text { high WVTR, low } \\
\text { WVP, can inhibit the } \\
\text { activity of E.coli and } \\
\text { S. aureus bacteria }\end{array}$ & [34] \\
\hline Gelatin & glycerol & $\begin{array}{l}\text { The film thickness } \\
\text { of } 0.13 \mathrm{~mm} \text { (thin), } \\
\text { not damp, high } \\
\text { WVP, high WVTR, } \\
\text { swelling behavior, } \\
\text { good tensile } \\
\text { strength, good } \\
\text { elongation, good } \\
\text { modulus elastic. }\end{array}$ & [35] \\
\hline Soybean & glycerol & $\begin{array}{l}\text { Film thickness } 76 \\
\mu \mathrm{m}, \quad \text { yellowish } \\
\text { transparent, fine } \\
\text { texture without } \\
\text { brittle, bad tensile } \\
\text { strength, good } \\
\text { modulus elastic, bad } \\
\text { elongation. }\end{array}$ & [36] \\
\hline
\end{tabular}

There are several advantages to using protein as an ingredient for making edible films, such as the availability of an abundant source of protein, the capability to form a good film, and also high in nutrients. The factor that makes protein widely used as a material for making films is its natural degradation or degradability. Compared to lipids and polysaccharides, protein-based films are the most beneficial due to their excellent gas barrier characteristics [32]. The oxygen permeability of soy protein-based films was lower than that of pectin, starch, polyethylene, methylcellulose, which were $670,540,500$, and 260 times lower, respectively. Besides that, protein-based films also have low density and generally have better mechanical properties than lipid-based and polysaccharide-based films [33].

Protein is a polymer formed from amino acids up to 20 monomers, which can provide a wider functional range, especially high intermolecular binding capabilities. Protein-based films can create bonds in different positions so that they can form many bonds, which makes the film structure more rigid [30]. The addition of auxiliary materials such as plasticizers can develop the ability of proteins to form films. The molecular weight, as well as the amount and position of the hydroxyl groups of the plasticizer, are variables that can affect the film formation capability of protein-based polymers [33]. Consequently, the plasticizer chosen will vary depending on the type of protein used.

\section{UTILIZATION OF WHEY PROTEIN AS MATERIAL FOR FILM PRODUCTION}

The availability of waste from the livestock industry is quite large. The cheese processing industry produces whey waste, which is often not utilized. It is known that whey waste has compounds that can pollute the environment. Whey has substanceBiochemical Oxygen Demand and Chemical Oxygen Demand that do not meet the permitted safe limits, namely $50 \mathrm{~g} / \mathrm{L}$ (BOD) and $80 \mathrm{~g} / \mathrm{L}$ (COD)[12], [37]. The choice of whey protein as another polymer material in film production because protein is known for its good mechanical characteristics. It is known that protein plays a significant role as a barrier to oxygen entering food packaging[38]. Other protein properties are transparent, soft, flexible, odorless, colorless, and have aroma-retaining properties from coated food products[39].

Fermented whey protein has high functional properties in the presence of bioactive peptides resulting from the degradation of microorganisms. It is known that these microorganisms hydrolyze protein then produce lysozyme, lactoferrin, and lactoperoxidase, which have antimicrobial properties[40]. In fermented whey, the lactoferrin peptides will be degraded by Candida tropicallis to produce lactoferricin, which has an antimicrobial effect[10]. In contrast, lysozyme is found mainly in the secretion of animal products such as milk, which is useful for naturally preventing excess microbial contamination. The work of lysozyme is to make microbial cells into lysis so that with the presence of lysozyme, the activity of microorganisms can be suppressed[9].

Various bioactive peptides can be obtained from cheese whey. Some of them are $\beta$-lactotensin, $\beta$-lactorphin, $\alpha$-lactorphin,serorphin,lactoferricin, $\quad$ and albutensin A [40]. However, the main bioactive peptides found in cheese whey acquired from whey protein hydrolysis are $\beta$-lactoglobulin $(\beta-\mathrm{LG})$ and $\alpha$-lactoalbumin $(\alpha-\mathrm{LA})$. The antimicrobial potential of the bioactive peptides acquired from this protein appears to be much less than that of lactoferrin. Whey protein cheese also contains immunoglobulins,lactoferrin,lactoperoxidase, and bovine 
Edy Subroto et al., International Journal of Emerging Trends in Engineering Research, 9(2), February 2021, 42 - 48

serum albumin, which also have antioxidant, antimicrobial, and immunomodulatory activities[41], [42].

\section{STARCH AND PROTEIN-BASED COMPOSITE FILMS}

Basically, the manufacture of starch and protein-based films into composites uses the gelation method. In the formation of gelation, a stabilizer or emulsifier is needed to strengthen the bonds between polymers. Based on the physicochemical properties associated with starch and protein formulations, both materials have hydrophilic and hydrophobic properties; therefore, it is necessary to append an emulsifier to make the solution more stable[43]. Addition of other components such as Carboxymethylcellulose (CMC) and Hydroxypropyl methylcellulose (HPMC) is added to make the starch more hydrophobic and make the starch form into a gel faster because it is water-soluble[8], [44].

In addition, to improve the physical characteristics of the film, a plasticizer is needed. Plasticizers are added to the formulation to increase flexibility and permeability. Generally, glycerol and sorbitol are materials that are almost always used because they are not toxic[39]. Glycerol is an ingredient that is very commonly used in film making formulations. The choice of glycerol as a plasticizer is because glycerol has good stability and is very compatible when reacting with hydrophilic polymers[45]. The compatibility of glycerol that reacts with starch is indicated by the easier it is for the starch-based components to dissolve in glycerol[43]. The use of glycerol aims to increase the elasticity of the film; however, it is not recommended to use too much glycerol. The use of glycerol above $50 \%$ will have an impact on the loosening of polymer bonds so that it will reduce the permeability of the film[34], [46].

Another thing that needs to be known after formulating is observing the microstructure of the film. Microstructure observations will represent the state of the surface and the inside of the film. The choice of basic material will affect the microstructure characteristics of the film to be made. The selection of protein as the basic material for making films can form smooth film characteristics without any folds, holes, or lumps after being observed with SEM (Scanning Electron Microscope)[47]. A positive thing is also shown in research[48], that mixing protein with starch does not change the microstructure of the film made because of the cross-linking process between polymers. Although the plasticizer is one of the important ingredients in film making, increasing the plasticizer dose up to 50\%can cause the film structure to become coarser[49].

The formation of polysaccharide-based films with the addition of more protein can also have an effect on color changes. The addition of more protein will cause the film to be more yellow in color but with a smooth and soft texture[25]. The color change that occurs is due to a high-temperature change in the film matrix, which causes the Maillard reaction[50].

\section{OTHER INGREDIENTS IN FILM FORMULATIONS}

\subsection{Plasticizer}

Plasticizers are defined by the IUPAC as substances or materials that are incorporated in a material to improvedistensibility, workability (chemical reactions), and flexibility[30]. A low amount of plasticizer is required to form a good film. The addition of plasticizers into polymer formulations can form a modified three-dimensional structure so as to degrade intermolecular forces and the movement of molecular chains and can increase volume[51]. The way the plasticizer works is by entering between polymer molecular chains (polysaccharides or proteins), then it will associate with these polymers through physical and chemical interactions, which will increase extensibility, flexibility, elasticity, and distensibility. In addition, the addition of a plasticizer can cause mechanical properties, cohesion, and stiffness to decrease[52]. Glycerol is a plasticizer that is often used because it has high hygroscopicity, which can reduce the level of the brittleness of the formed film[53].

The effect of adding plasticizers to the formulation depends on the molecular size of plasticizers, physical state,polarity,shape, the number of oxygen atoms, and their distance in the polyol structure[54]. The addition of a plasticizer can also reduce intermolecular forces and increase the mobility of the polymer chains, which give more flexibility tobiomaterials and result in less brittleness and stiffness. Glycerol generally exerts the most pronounced impact on the thermal and mechanical properties of the film but negatively affects the barrier properties. In contrast to polyethylene glycol and sorbitol, in their role as plasticizers in films, they generally show better mechanical properties and lower WVP when compared to the plasticizing effect of glycerol[55].

\subsection{Essential oil}

Essential oils are generally used in edible films to enhance antimicrobial properties. The concentration used in the formulation must be considered; low concentrations of essential oils do not cause any effect. However, at concentrations too high, it is feared that essential oils can cause allergic reactions and toxicological effects because the film to be made is an edible film[56].The addition of essential oils to the film formulation provides a good antimicrobial effect. The antimicrobial property serves to keep foodstuffs covered by the film from microbiological damage[57]. Many ingredients can be extracted from their essential oil, especially in plant species. Frankincense oil can be used as a source of essential oils, which shows a strong level of antioxidant activity characterized by the large number of free radicals that are bound as a result of the presence of terpenes, which also acts as an antimicrobial. Terpenesare compoundsthat can act asan electron donor to react with free radicals to produce a more stable product; therefore,the free radical activity can be suppressed[58].

Essentialoils have low water solubility; it is difficult to enter between the existing monomers. This is because the 
Edy Subroto et al., International Journal of Emerging Trends in Engineering Research, 9(2), February 2021, 42 - 48

particle size of essential oils is relatively large, and essential oils also cause the film that is formed to be darker in color compared to films that do not use essential oils in the formulation[59]. A similar thing was indicated by Akhter et al.[60], that the level of roughness on the surface of the composite film when mixing mint leaf essential oil increased. The essential oil could be encapsulated into oil in a water emulsion to increase the essential oil dispersion in the chitosan matrix so thatit increase its compatibility with the chitosan matrix. Another solution that can be used is to make essential oil nanoemulsion, which makes the particle size smaller, uniform, and stable so that darkening of the film color can also be avoided. Therefore, it is recommended to use essential oils that have passed nanoemulsification[61].

\section{CONCLUSION}

The production of edible films with polysaccharide-based materials has the potential to continue to be developed because of the availability of cheap raw materials, and its continuity is maintained, but the resulting edible film has mechanical properties that must be improved. In another case with protein, the resulting mechanical properties give fairly good results, but the color of the film is generally more yellowish. The addition of a plasticizer to the formulation needs to be done to improve the mechanical properties of the film to make it stronger. However, the addition of this plasticizer needs to be limited in use because it will cause an unfavorable texture on the formed film. In addition, to increase the antimicrobial properties of the film, essential oils can be added, but their use must be limited because essential oils have a large molecular size, so that it can be difficult to penetrate the monomer cavities in the edible film.

\section{ACKNOWLEDGEMENT}

The authors would like to thank the Rector of UniversitasPadjadjaran and the Ministry of Education and Culture of the Republic of Indonesia for the support provided.

\section{REFERENCES}

1. S. M. Chisenga, G. N. Tolesa, and T. S. Workneh, "Biodegradable Food Packaging Materials and Prospects of the Fourth Industrial Revolution for Tomato Fruit and Product Handling," Int. J. Food Sci., vol. 2020, p. 8879101, 2020.

2. O. Erkmen and A. O. Barazi, "General Characteristics of Edible Films," J. Food Biotechnol. Res., vol. 2, no. 1.3, pp. 1-4, 2018.

3. M. Guldas, A. Akpinar-Bayizit, T. Ozcan, and L. Yilmaz-Ersan, "Effects of edible film coatings on shelf-life of mustafakemalpasa sweet, a cheese based dessert," J. Food Sci. Technol., vol. 47, no. 5, pp. 476-481, 2010.

4. D. Hasnelly, D. Ina SitiNurminabari, and T. MochErganUtamaNasution, "Pemanfaatan Whey $\begin{array}{lll}\text { SusuMenjadi } & \text { Edible } & \text { Film }\end{array}$
SebagaiKemasanDenganPenambahanCmc, Gelatin Dan Plasticizer," Pas. Food Technol. J., vol. 2, no. 1, pp. 62-69, 2015.

5. C. G. Otoni et al., "Recent Advances on Edible Films Based on Fruits and Vegetables-A Review," Compr. Rev. Food Sci. Food Saf., vol. 16, no. 5, pp. 1151-1169, 2017.

6. K. E. Basuki, Jariyah, and D. D. Hartati, "Karakteristik Edible Film Dari PatiUbiJalar Dan Gliserol," RekaPangan, vol. 8, no. 2, pp. 128-135, 2014.

7. M. Chiumarelli and M. D. Hubinger, "Evaluation of edible films and coatings formulated with cassava starch, glycerol, carnauba wax and stearic acid," Food Hydrocoll., vol. 38, pp. 20-27, 2014.

8. I. Dinika, D. K. Verma, R. Balia, G. L. Utama, and A. R. Patel, "Potential of cheese whey bioactive proteins and peptides in the development of antimicrobial edible film composite: A review of recent trends," Trends Food Sci. Technol., vol. 103, no. July, pp. 57-67, 2020.

9. C. A. Campos, L. N. Gerschenson, and S. K. Flores, "Development of Edible Films and Coatings with Antimicrobial Activity," Food Bioprocess Technol., vol. 4, no. 6, pp. 849-875, 2011.

10. F. Utba, R. L. Balia, and G. L. Utama, "The Presence of Indigenous Yeasts WithProteolytic Activity Isolated From Homemade-Mozzarella Whey," Sci. Pap. Ser. Manag. Econ. Eng. Agric. Rural Dev., vol. 18, no. 1, pp. 507-514, 2018.

11. A. Maghfirah, A. Sembiring, M. Iskandar, M. A. Rambe, and E. Marlianto, "KarakteristikPlastik Edible Film DenganPemanfaatanPatiKulitUbiKayu (Manihotutilissima Pohl.) dan Keratin BuluAyam," J. Islam. Sci. Technol., vol. 3, no. 1, pp. 12-17, 2018.

12. I. H. Yusrina, R. Purwasih, and F. Fathurohman, "PemanfaatanLimbahKeju Mozzarella sebagaiMinumanFungsionaldenganPenambahan Rasa Nanas danJeruk Siam,” Bull. Appl. Anim. Res., vol. 1, no. 1, pp. 1-7, 2019.

13. M. L. Sanyang, S. M. Sapuan, M. Jawaid, M. R. Ishak, and J. Sahari, "Effect of plasticizer type and concentration on tensile, thermal and barrier properties of biodegradable films based on sugar palm (Arengapinnata) starch," Polymers (Basel)., vol. 7, no. 6, pp. 1106-1124, 2015.

14. B. Hassan, S. A. S. Chatha, A. I. Hussain, K. M. Zia, and N. Akhtar, "Recent advances on polysaccharides, lipids and protein based edible films and coatings: A review," Int. J. Biol. Macromol., vol. 109, pp. 1095-1107, 2018.

15. S. A. A. Mohamed, M. El-Sakhawy, and M. A.-M. El-Sakhawy, "Polysaccharides, Protein and Lipid -Based Natural Edible Films in Food Packaging: A Review," Carbohydr. Polym., vol. 238, no. March, p. 116178, 2020.

16. E. Subroto, A. D. Pangawikan, V. P. Yarlina, and N. F. Isnaeni, "Characteristics, Purification, and the Recent Applications of Soybean Oil in Fat-Based Food Products : A Review," Int. J. Emerg. Trends Eng. Res., vol. 8, no. 7, pp. 3003-3011, 2020. 
17. V. D. Alves, N. Costa, and I. M. Coelhoso, "Barrier properties of biodegradable composite films based on kappa-carrageenan/pectin blends and mica flakes," Carbohydr. Polym., vol. 79, no. 2, pp. 269-276, 2010.

18. T. P. Singh, M. K. Chatli, and J. Sahoo, "Development of chitosan based edible films: process optimization using response surface methodology," J. Food Sci. Technol., vol. 52, no. 5, pp. 2530-2543, 2015.

19. J. F. Mendes, L. B. Norcino, A. Manrich, A. C. M. Pinheiro, J. E. Oliveira, and L. H. C. Mattoso, "Characterization of Pectin Films Integrated with Cocoa Butter by Continuous Casting: Physical, Thermal and Barrier Properties," J. Polym. Environ., vol. 28, no. 11, pp. 2905-2917, 2020.

20. W. Lan et al., "Improving nisin production by encapsulated Lactococcuslactis with starch/carboxymethyl cellulose edible films," Carbohydr. Polym., vol. 251, no. September 2020, 2021.

21. Z. Mahcene et al., "Development and characterization of sodium alginate based active edible films incorporated with essential oils of some medicinal plants," Int. J. Biol. Macromol., vol. 145, pp. 124-132, 2020.

22. S. Li et al., "Cassava starch/carboxymethylcellulose edible films embedded with lactic acid bacteria to extend the shelf life of banana," Carbohydr. Polym. vol. 248, no. July, p. 116805, 2020.

23. P. Zhang, Y. Zhao, and Q. Shi, "Characterization of a novel edible film based on gum ghatti: Effect of plasticizer type and concentration," Carbohydr. Polym., vol. 153, pp. 345-355, 2016.

24. P. R. Fitch-Vargas et al., "Physicochemical and Microstructural Characterization of Corn Starch Edible Films Obtained by a Combination of Extrusion Technology and Casting Technique," J. Food Sci., vol. 81, no. 9, pp. E2224-E2232, 2016.

25. K. Huntrakul, R. Yoksan, A. Sane, and N. Harnkarnsujarit, "Effects of pea protein on properties of cassava starch edible films produced by blown-film extrusion for oil packaging," Food Packag. Shelf Life, vol. 24, no. August 2019, p. 100480, 2020.

26. T. Adiyanti and E. Subroto, "Modifications Of Banana Starch And Its Characteristics : A Review," Int. J. Sci. Technol. Res., vol. 9, no. 3, pp. 3-6, 2020.

27. C. L. Murrieta-Martínez, H. Soto-Valdez, R. Pacheco-Aguilar, W. Torres-Arreola, F. Rodríguez-Felix, and E. Márquez Ríos, "Edible protein films: Sources and behavior," Packag. Technol. Sci., vol. 31, no. 3, pp. 113-122, 2018.

28. M. Letendre, G. D’Aprano, M. Lacroix, S. Salmieri, and D. St-Gelais, "Physicochemical properties and bacterial resistance of biodegradable milk protein films containing agar and pectin," J. Agric. Food Chem., vol. 50, no. 21, pp. 6017-6022, 2002.

29. L. D. Pérez-Vergara, M. T. Cifuentes, A. P. Franco, C. E. Pérez-Cervera, and R. D. Andrade-Pizarro, "Development and characterization of edible films based on native cassava starch, beeswax, and propolis," NFS J., vol. 21, no. September, pp. 39-49, 2020.
30. H. Chen et al., "Application of protein-based films and coatings for food packaging: A review," Polymers (Basel)., vol. 11, no. 12, pp. 1-32, 2019.

31. Y. R. Wagh, H. A. Pushpadass, F. M. E. Emerald, and B. S. Nath, "Preparation and characterization of milk protein films and their application for packaging of Cheddar cheese," J. Food Sci. Technol., vol. 51, no. 12, pp. 3767-3775, 2014.

32. B. R. A. Hurley, A. Ouzts, J. Fischer, and T. Gomes, "Effects of Private and Public Label Packaging on Consumer Purchase Patterns,' Packag. Technol. Sci., vol. 29, no. January, pp. 399-412, 2013.

33. T. Bourtoom, "Edible protein films: Properties enhancement," Int. Food Res. J., vol. 16, no. 1, pp. 1-9, 2009.

34. H. Çakmak, Y. Özselek, O. Y. Turan, E. Fıratlıgil, and F. Karbancioğlu-Güler, "Whey protein isolate edible films incorporated with essential oils: Antimicrobial activity and barrier properties," Polym. Degrad. Stab., vol. 179, p. 109285, 2020.

35. D. Khodaei, K. Oltrogge, and Z. Hamidi-Esfahani, "Preparation and characterization of blended edible films manufactured using gelatin, tragacanth gum and, Persian gum," LWT - Food Sci. Technol., vol. 117, no. February 2019, p. 108617, 2020.

36. A. González, G. N. Barrera, P. I. Galimberti, P. D. Ribotta, and C. I. Alvarez Igarzabal, "Development of edible films prepared by soy protein and the galactomannan fraction extracted from Gleditsiatriacanthos (Fabaceae) seed," Food Hydrocoll., vol. 97, no. February, p. 105227, 2019.

37. P. M. R. Guimarães, J. A. Teixeira, and L. Domingues, "Fermentation of lactose to bio-ethanol by yeasts as part of integrated solutions for the valorisation of cheese whey," Biotechnol. Adv., vol. 28, no. 3, pp. 375-384, 2010.

38. M. Javanmard, "Effect of whey protein edible film packaging on the quality and moisture uptake of dried peanuts," J. Food Process Eng., vol. 31, no. 4, pp. 503-516, 2008.

39. I. Hudha, K. Dewi, J. Fitri, and N. Ayu, "PotensiLimbahKeju (Whey) sebagaiBahanPembuatanPlastikPengemas yang Ramah Lingkungan," J. Tek. Media Pengemb. IlmudanApl. Tek., vol. 19, no. 1, pp. 46-52, 2020.

40. D. Isfari and G. L. Utama, "Cheese whey as potential resource for antimicrobial edible film and active packaging production," Foods Raw Mater., vol. 7, no. 2, pp. 229-239, 2019.

41. B. Dziuba and M. Dziuba, "Milk proteins-derived bioactive peptides in dairy products: Molecular, biological and methodological aspects," Acta Sci. Pol. Technol. Aliment., vol. 13, no. 1, pp. 5-25, 2014.

42. B. Rezaharsamto and E. Subroto, "A Review On Bioactive Peptides Derived From Various Sources Of Meat And Meat By-Products," Int. J. Sci. Technol. Res., vol. 8, no. 12, pp. 3151-3156, 2019.

43. S. H. Siregar and W. Irma, "PemanfaatanKulitSingkongSebagaiAlternatifBahan 
Edy Subroto et al., International Journal of Emerging Trends in Engineering Research, 9(2), February 2021, 42 - 48

Baku Edible Film,” Phot. J. SaindanKesehat., vol. 3, no. 1, pp. 15-21, 2012.

44. A. C. Oluwaseun, A. AroworaKayode, F. O. Bolajoko, A. J. Bunmi, and A. R. Olagbaju, "Effect of edible coatings of carboxy methyl cellulose and corn starch on cucumber stored at ambient temperature," Asian J. Agric. Biol., vol. 1, no. 3, pp. 133-140, 2013.

45. S. Chillo, S. Flores, M. Mastromatteo, A. Conte, L. Gerschenson, and M. A. Del Nobile, "Influence of glycerol and chitosan on tapioca starch-based edible film properties," J. Food Eng., vol. 88, no. 2, pp. 159-168, 2008.

46. S. Sukhija, S. Singh, and C. S. Riar, "Analyzing the effect of whey protein concentrate and psyllium husk on various characteristics of biodegradable film from lotus (Nelumbonucifera) rhizome starch.," Food Hydrocoll., vol. 60, pp. 128-137, 2016.

47. K. S. Silva, T. M. R. Fonseca, L. R. Amado, and M. A. Mauro, "Physicochemical and microstructural properties of whey protein isolate-based films with addition of pectin," Food Packag. Shelf Life, vol. 16, no. March, pp. 122-128, 2018.

48. Z. Zareie, F. TabatabaeiYazdi, and S. A. Mortazavi, "Development and characterization of antioxidant and antimicrobial edible films based on chitosan and gamma-aminobutyric acid-rich fermented soy protein," Carbohydr. Polym., vol. 244, no. March, p. 116491, 2020.

49. S. Jafarzadeh, A. K. Alias, F. Ariffin, and S. Mahmud, "Physico-mechanical and microstructural properties of semolina flour films as influenced by different sorbitol/glycerol concentrations," Int. J. Food Prop., vol. 21, no. 1, pp. 983-995, 2018.

50. C. J. R. Verbeek and L. E. Van Den Berg, "Extrusion processing and properties of protein-based thermoplastics," Macromol. Mater. Eng., vol. 295, no. 1, pp. 10-21, 2010.

51. S. N. Swain, S. M. Biswal, P. K. Nanda, and P. L. Nayak, "Biodegradable Soy-Based Plastics: Opportunities and Challenges," J. Polym. Environ., vol. 12, pp. 35-42, 2004.

52. D. Ananey-Obiri, L. Matthews, M. H. Azahrani, S. A. Ibrahim, C. M. Galanakis, and R. Tahergorabi, "Application of protein-based edible coatings for fat uptake reduction in deep-fat fried foods with an emphasis on muscle food proteins," Trends Food Sci. Technol., vol. 80, pp. 167-174, 2018.

53. E. Kristo and C. G. Biliaderis, "Water sorption and thermo-mechanical properties of water/sorbitol-plasticized composite biopolymer films: Caseinate-pullulan bilayers and blends," Food Hydrocoll., vol. 20, no. 7, pp. 1057-1071, 2006.

54. O. Rompothi, P. Pradipasena, K. Tananuwong, A. Somwangthanaroj, and T. Janjarasskul, "Development of non-water soluble, ductile mung bean starch based edible film with oxygen barrier and heat sealability," Carbohydr. Polym., vol. 157, pp. 748-756, 2017.

55. C. Gao, E. Pollet, and L. Avérous, "Innovative plasticized alginate obtained by thermo-mechanical mixing: Effect of different biobasedpolyols systems," Carbohydr. Polym., vol. 157, pp. 669-676, 2017.

56. L. Sánchez-González, M. Vargas, C. González-Martínez, A. Chiralt, and M. Cháfer, "Use of Essential Oils in Bioactive Edible Coatings: A Review," Food Eng. Rev., vol. 3, no. 1, pp. 1-16, 2011.

57. M. S. Abdel Aziz, H. E. Salama, and M. W. Sabaa, "Biobased alginate/castor oil edible films for active food packaging," LWT - Food Sci. Technol., vol. 96, pp. 455-460, 2018.

58. B. Prakash, P. K. Mishra, A. Kedia, and N. K. Dubey, "Antifungal, antiaflatoxin and antioxidant potential of chemically characterized BoswelliacarteriiBirdw essential oil and its invivo practical applicability in preservation of Piper nigrum L. fruits," LWT - Food Sci. Technol., vol. 56, no. 2, pp. 240-247, 2014.

59. Z. Flores, D. San Martín, R. Villalobos-Carvajal, G. Tabilo-Munizaga, F. Osorio, and J. Leiva-Vega, "Physicochemical characterization of chitosan-based coating-forming emulsions: Effect of homogenization method and carvacrol content," Food Hydrocoll., vol. 61, pp. 851-857, 2016.

60. R. Akhter, F. A. Masoodi, T. A. Wani, and S. A. Rather, "Functional characterization of biopolymer based composite film: Incorporation of natural essential oils and antimicrobial agents," Int. J. Biol. Macromol., vol. 137, pp. 1245-1255, 2019.

61. S. Shokri, K. Parastouei, M. Taghdir, and S. Abbaszadeh, "Application an edible active coating based on chitosan- Ferulagoangulata essential oil nanoemulsion to shelf life extension of Rainbow trout fillets stored at $4{ }^{\circ} \mathbf{C}$," Int. J. Biol. Macromol., vol. 153, pp. 846-854, 2020. 